Southern Illinois University Carbondale

OpenSIUC

Articles

Morris Library

$1-2007$

\title{
Library Faculty Publishing and Intellectual Property Issues: A Survey of Attitudes and Awareness
}

Howard Carter

Southern Illinois University Carbondale, hcarter@lib.siu.edu

Carolyn A. Snyder

Southern Illinois University Carbondale, csnyder@lib.siu.edu

Andrea Imre

Southern Illinois University Carbondale, aimre@lib.siu.edu

Follow this and additional works at: http://opensiuc.lib.siu.edu/morris_articles

Part of the Library and Information Science Commons

Published in portal: Libraries and the Academy 7, No. 1 (2007): 65-79.

\section{Recommended Citation}

Carter, Howard, Carolyn Snyder, and Andrea Imre. "Library Faculty Publishing and Self-Archiving: A Survey of Attitudes and Awareness." portal: Libraries and the Academy 7, No. 1 (2007): 65-79. Link to publisher version.

This Article is brought to you for free and open access by the Morris Library at OpenSIUC. It has been accepted for inclusion in Articles by an authorized administrator of OpenSIUC. For more information, please contact opensiuc@lib.siu.edu. 


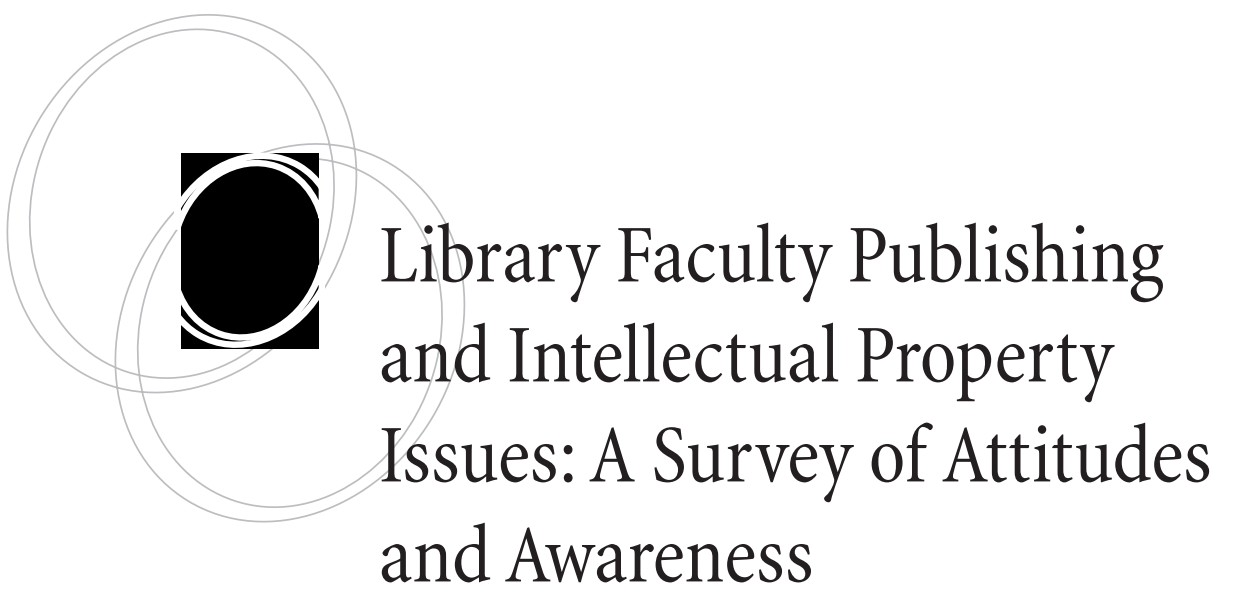

Howard Carter, Carolyn A. Snyder, and Andrea Imre

abstract:Researchers from Southern Illinois University Carbondale (SIUC) surveyed faculty members from 10 academic research libraries to learn about scholarly publishing activities, attitudes, and policies. Areas of special interest included the effect of publishers' intellectual property policies and institutional promotion and tenure processes on library faculty publishing decisions. The library faculty members were also asked about their experience in negotiating for additional rights from publishers and their experience in self-archiving their research. The researchers wanted to determine if there were any correlation between a library faculty member's rank and tenure status and the number of peer-reviewed articles published in refereed journals.

\section{Introduction}

I n August 2005, researchers from Southern Illinois University Carbondale (SIUC) surveyed faculty members from 10 academic research libraries to learn about scholarly publishing activities, attitudes, and policies. Areas of special interest included the effect of publishers' intellectual property policies and of institutional promotion and tenure processes on faculty publishing decisions. Faculty members were asked about their experience in negotiating for additional rights from publishers and their experience in self-archiving their research. The researchers wanted to determine whether library faculty members who published journal articles were asking for additional intellectual property rights and were self-archiving more often than faculty members in all disciplines combined. They also wanted to ascertain if library faculty members practice what they generally advocate about providing easier and less expensive access to the journal literature. The correlation between a faculty member's rank and tenure status and the number of articles published in refereed journals was also studied and reported.

portal: Libraries and the Academy, Vol. 7, No. 1 (2007), pp. 65-79.

Copyright @ 2007 by The Johns Hopkins University Press, Baltimore, MD 21218. 
To gain these insights about scholarly publishing among library faculty members, the researchers at Southern Illinois University Carbondale (SIUC) determined that a useful and relevant survey group would be the library faculty members of nine peer institutions of SIUC and the library faculty members at SIUC. This allowed for the study of the attitudes and awareness of the library faculty members of comparable mid-size research institutions in which librarians hold faculty status. Nine of the 10 institutions surveyed are members of the Association of Research Libraries. The findings, therefore, should be of interest to research librarians nationally and internationally and especially to other members of the Association of Research Libraries. There was a good response rate from a reasonable population.

Faculty members were asked to identify their institution, faculty rank, and tenure status and to indicate when tenure was granted. They were also asked about articles they had published in scholarly journals in the past five years and whether or not publishers' intellectual property and copyright policies affected the choice of journals to which articles were submitted. Faculty members were asked if they had ever tried to negotiate for more rights than those offered by the publishers and to indicate their attitude toward and experience with self-archiving their research. Individual respondents were assured of their anonymity because of the design of the Web survey instrument. The researchers were also interested in the promotion and tenure policies and procedures of the 10 institutions and any effect they had on the scholarly publishing activities of the library faculty.

\section{Selected Literature Review}

The literature review focused on recent studies in North America of library faculty publishing and library faculty responses to intellectual property rights and self-archiving. The search for major studies and developments in intellectual property rights and selfarchiving for all faculty disciplines also included the international literature.

Studies about the publishing behavior of library faculty included several recent articles that involved all types of academic institutions both with and without faculty status. The Florida study by Deborah Henry and Tina Neville included 73 public and private institutions of higher education. The authors stated that "in an effort to establish benchmarks for comparison to national trends, a web-based survey explored research, publication, and service activities of Florida academic librarians. Participants ranked the importance of professional activities to the tenure/ promotion process. Findings suggest that perceived tenure and promotion demands do influence research productivity."1

The Illinois case study by Kathleen Joswick of article publication patterns by librarians from all types of academic libraries focused on collaboration, numbers of publications, and the publication patterns and choices. The study concluded that librarians in Illinois academic libraries are active in research and publication. Their collaborative work continues to grow, especially among female authors. More librarians from large institutions are authors than librarians from smaller institutions. ${ }^{2}$

Richard Hart studied scholarly publication by university librarians at Pennsylvania State University, an institution that requires librarians to publish as a condition of continued employment. The findings suggested that the increased demands in recent 
years for librarians to publish have resulted in an increase in the quality and quantity of their publications and in a shift to more publications in refereed journals and core library publications. Although the study focused on the one institution where publishing expectations are strong, the author noted that similar findings might be observed in other libraries with strong publishing requirements. ${ }^{3}$

The May 2006 issue of College and Research Libraries included three articles about faculty status; one article is relevant to the SIUC findings. The Stephen Wiberley, Julie Hurd, and Ann Weller article, "Publication Patterns of U.S. Academic Librarians from 1998 to 2002," focused on the peer-reviewed literature of library and information science. The study results compared the researchers' earlier report of publishing between 1993 and 1997. Both studies asked the same questions about the proportion of articles by academic librarians in the peer-reviewed literature, frequency of sole authorship and co-authorship, types of libraries with the most productive librarians, and productivity benchmarks for academic librarians. The researchers conclusions included:

1. To be among the top 10 percent in productivity, three referred articles in a threeyear period are necessary.

2. Forty-one percent of articles by academic librarians are co-authored.

3. The most productive libraries are those in research "extensive" universities. ${ }^{4}$

In the area of intellectual property rights, our literature review included copyright transfer agreements with a special focus on self-archiving. The literature review documented that in recent years most publishers have changed their copyright transfer policies to allow authors to retain more rights today than in the past, including the right to self-archive articles.

Authors sign publisher copyright transfer agreements at the time their work is accepted for publication. Copyright transfer agreements require that authors transfer to the publisher some or all of the exclusive rights granted by the U. S. copyright law. These exclusive rights include the right to reproduce, distribute, make "derivative" works, publicly perform, and publicly display the copyrighted work. Previous studies indicated that authors do not show much interest in copyright transfer agreements. Ian Rowlands, Dave Nicholas, and Paul Huntingdon's report found that only 13 percent of authors took a "detailed interest," and 46 percent took no interest in copyright. ${ }^{5}$ Alma Swan and Sheridan Brown examined the knowledge and attitude toward copyright of 1,296 authors. They found that 22 percent did not know who retained copyright, 35 percent reported that they retained copyright, 37 percent said that the publisher was the copyright holder, and 6 percent indicated another party as the copyright holder. ${ }^{6}$ The first RoMEO (Rights Metadata for Open Archiving) survey results showed that only 3 percent of authors insisted on retaining copyright, with 49 percent assigning copyright to publishers reluctantly, 41 percent assigning it freely, and 7 percent indicating that publishers did not retain copyright. ${ }^{7}$

Copyright transfer agreements are important elements in the open access discussion because these agreements govern what authors are allowed to do with their papers. Several advocates, including Steven Harnad and participants in the Budapest Open Access Initiative, emphasized that one of the rights that authors should seriously consider retaining is the right to self-archive. ${ }^{8}$ Self-archiving is a method used by authors to 
deposit research papers in freely accessible online archives to allow wider dissemination of their research.

In July 2002, Mark Frankel concluded in the report on scientists' authorship rights that "scientists should be more assertive in claiming their intellectual property rights and that they leverage those rights to increase access to and use of their works through more creative and expanded use of licensing." ${ }^{\prime 9}$ Whereas it is true that the science, technology, and medicine (STM) sector of the publishing industry generally produces the most expensive journals, researchers in other disciplines including library and information science share this conclusion about intellectual property rights. Peter Suber noted, "There is a serious problem [serials pricing and permission crisis], known best to librarians, and a beautiful solution [open access] within the reach of scholars. ${ }^{10}$ One can draw the conclusion from Suber's statement that librarians as authors should be the most prominent supporters of open access and that, as scholars, they would practice self-archiving.

The RoMEO and the SHERPA (Securing a Hybrid Environment for Research Preservation and Access) projects in the United Kingdom are leaders in the study of selfarchiving, including authors' views, publishers' policies, and other related scholarly communications issues. RoMEO, funded by the Joint Information Systems Committee (JISC), sponsored six studies related to the self-archiving activities of authors and to publishers' copyright transfer agreements. ${ }^{11}$ In 2002-2003, the first RoMEO study showed that only 42.5 percent of the 80 publishers examined allowed self-archiving, so it was concluded that "authors or institutions that wish to self-archive are in 50 percent of the cases unable to do so."12 The RoMEO project also resulted in the establishment of the publisher's copyright listings database, now hosted by SHERPA, which includes summaries of authors' pre-print and post-print archiving rights, conditions of selfarchiving, links to publishers' copyright transfer agreements, and the RoMEO color classification code for each entry (indicating the level of self-archiving rights granted by the publisher). Currently, 78 percent of 149 publishers included in the database allow some form of self-archiving. ${ }^{13}$

Yet, as Lee C. Van Orsdel and Kathleen Born noted, many authors do not exercise their rights to self-archive. ${ }^{14}$ The second RoMEO study revealed that only 58 percent of 536 authors made their articles freely available on the Web. ${ }^{15}$ Swan and Brown's international study showed that 40 percent of their survey group had self-archived at least once in the last three years, whereas 36 percent of all authors were unaware of the option of providing open access to their works by self-archiving. They noted that the subject with the highest number of freely available self-archived articles was computer science. ${ }^{16}$ The preliminary report of an online survey conducted by Anita Coleman and Joseph Roback showed that 55 percent of the library and information science authors surveyed practiced self-archiving. ${ }^{17}$

In March 2004, Rowlands, Nicholas, and Huntingdon reported the findings of an international study of author opinion about what the authors want from the journals system during this time of change and uncertainty. This study, referenced earlier in this section, was published by CIBER. The views and attitudes of nearly 4,000 senior researchers from 97 countries, including their levels of awareness of current issues and attitudes toward publishers and of the open access movement, were reported. Authors 
determine where to publish by considering a journal's readership, inclusion in abstracting and indexing services, impact factor, editorial board, online version availability, size of readership, speed of refereeing, hard copy availability, manuscript rejection rate, and price. $^{18}$

\section{Survey Methodology}

Researchers at SIUC developed a 10-question online survey instrument to gain insights about the publishing activity of library faculty, including their awareness of copyright and intellectual property policies of publishers of scholarly journals and their willingness to self-archive their published articles. The first four questions dealt with basic demographic information: institution name, faculty rank, tenure status, and date that tenure was granted. The remaining questions asked about the respondents' publishing decisions and experience with self-archiving. Figure 1 contains the survey questions that were asked. Respondents were also given the opportunity to add comments at the end of the survey.

1. Which of the following is your institution?

2. What is your faculty rank?

3. What is your tenure status?

4. If tenured, in which year were you granted tenure?

5. How many peer-reviewed articles have you had published in scholarly journals during the last 5 years (since January 1, 2000)?

6. Do you consider the publishers' copyright/intellectual property policies in deciding where to submit articles for publication?

7. If you knew that one publisher had a more generous copyright policy for authors than another publisher, would it influence your decision about the journal to which you submitted your article?

8. Have you ever negotiated for more author rights than were offered by the publisher?

9. If mandated by your institution, would you deposit copies of your articles in an institutional or subject-based repository? [Swan and Brown, "Open access self-archiving," JISC report, May 2005]

10. Have you self-archived any of your published articles?

Figure 1. Survey Questions

The survey instrument and the cover letter were approved by the SIUC Human Subjects Committee prior to distribution. An online survey generator program was used to create a survey that respondents could access via the Web. The survey was housed on a SIUC Library server, and responses were stored in a database for analysis. The survey was sent to the faculty of the SIUC Library and the library faculties of nine of the peer and aspirational peer institutions identified by the SIUC "Southern at 150" final report. ${ }^{19}$ Figure 2 is a listing of those institutions. 


\section{Auburn University \\ Iowa State University \\ Kansas State University \\ Louisiana State University* \\ Oklahoma State University \\ Texas Tech University \\ University of Colorado at Boulder* \\ University of Kentucky* \\ Washington State University \\ * Aspirational Peer}

Figure 2. SIUC Peer Institutions

The dean/ director of each library to be surveyed was contacted to secure support for the research project. The library deans / directors were asked for contact information for their faculty members, publication information for current faculty members, and copies of their promotion and tenure policies and procedures. They were also asked if they would provide a list of e-mail addresses for their faculty members so that the faculty members could be contacted directly by the researchers. They all responded positively, and one dean offered to send a copy of the solicitation letter to her faculty through their internal e-mail list. These library deans / directors were also asked to provide a list of citations for articles published by their faculty members since January 1, 2000. Several responded that they did not keep such records and that faculty members should be asked directly for their publishing history. Those faculty members were given the option of including their citations in the comments section of the online survey form or sending them directly to a research team member via e-mail. By sending their citation list in a separate message, anonymity of the survey responses was assured.

In August 2005, e-mail messages requesting library faculty participation in the research study were sent directly to faculty members of eight university libraries by using the addresses provided by the library administrators. One library dean distributed the message through the library's internal e-mail list. The library faculty at SIUC received the survey message through the internal e-mail list. A follow-up request was sent in September 2005.

\section{Findings}

Of the approximately 330 library faculty members who received the solicitation, 140 individuals responded. The overall response rate was approximately 41 percent. Institutions' response rates ranged from a high of 64 percent (SIUC) to a low of 30 percent for one institution, with a median response rate of 39 percent. The total number of responses by institution ranged from a high of 21 to a low of 10, and the mean and median number of responses was 14 . Recipients of the solicitation were given the opportunity to formally opt out of the research project. One person who was new to the profession chose to opt out. Figure 3 shows the number of responses received from the 10 institutions. 


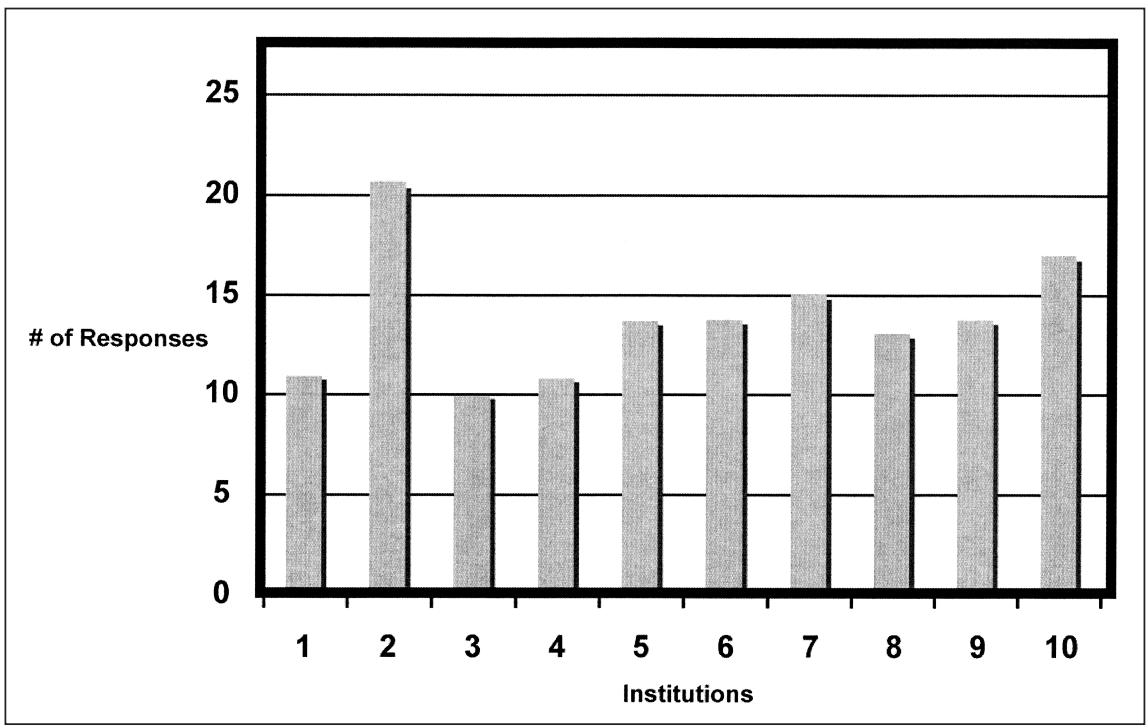

Figure 3. Responses by Institution

Survey respondents were asked to indicate their faculty rank and tenure status. The rank distribution is shown in figure 4 . The "other" category includes respondents who indicated they are instructors (2), librarian II (1), and librarian III (1).

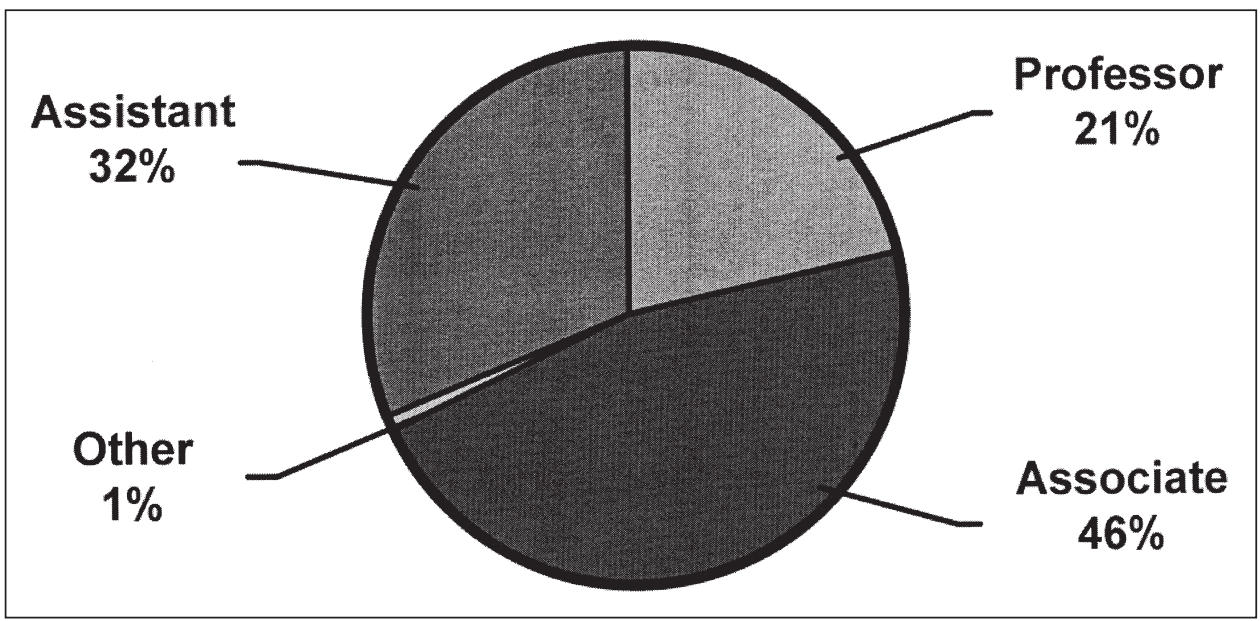

Figure 4. Faculty Ranks

The tenure status of respondents is shown in figure 5 . When asked the date of their tenure, 46 percent replied it was the year 2000 or before, and 33 percent either indicated "not applicable" or did not respond to the question. The remaining 21 percent were tenured between 2001 and 2005, with 2 percent in 2003 (the low) and 7 percent in 2004 (the high). 


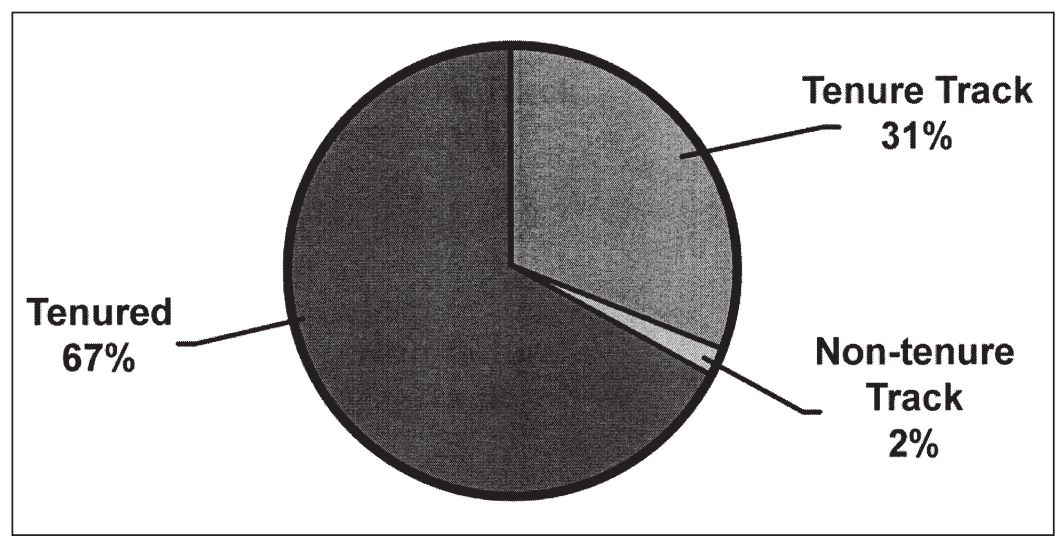

Figure 5. Tenure Status

\section{Scholarly Publishing and Self-Archiving Activity}

There were 137 respondents to the question about the number of peer-reviewed articles published in scholarly publications since January 1, 2000. There were 89 respondents (65 percent) who indicated that they had published at least one such article. Those 89 people said they had published a total of 288 articles during the period in question. One respondent indicated 14 published articles, one published 12, and another 10. The median number of articles for this group was three, and the mean was 3.22 , with a standard deviation of 2.43 .

The SIUC researchers gathered information about the number of library faculty authors who made an effort to negotiate for more rights than provided by the publishers' standard copyright transfer agreement and about the number who exercised their rights to self-archive if allowed by the publishers. Survey participants were asked

When asked if they considered those copyright and intellectual property policies when selecting a journal for article submission, 50 percent of the respondents indicated that their only concern was to have the article published. about their awareness of the copyright and intellectual property policies of the journal publishers when they submitted articles for publication. When asked if they considered those copyright and intellectual property policies when selecting a journal for article submission, 50 percent of the respondents indicated that their only concern was to have the article published. In the CIBER study, 46 percent indicated that they had no interest in the copyright and intellectual property policies; 55 percent of North American respondents indicated no interest. ${ }^{20}$ In that study, 13 percent indicated that they had a detailed interest. Only 10 percent of the SIUC study respondents indicated that they considered intellectual property and copyright policies when deciding on a potential publisher, and 36 percent said that those policies "somewhat" affected their decision. Six people (4 percent) did not answer this question. Therefore, the library faculty authors in this study expressed approximately the same degree of interest in copyright and intellectual property as the international, multidisciplinary group. 


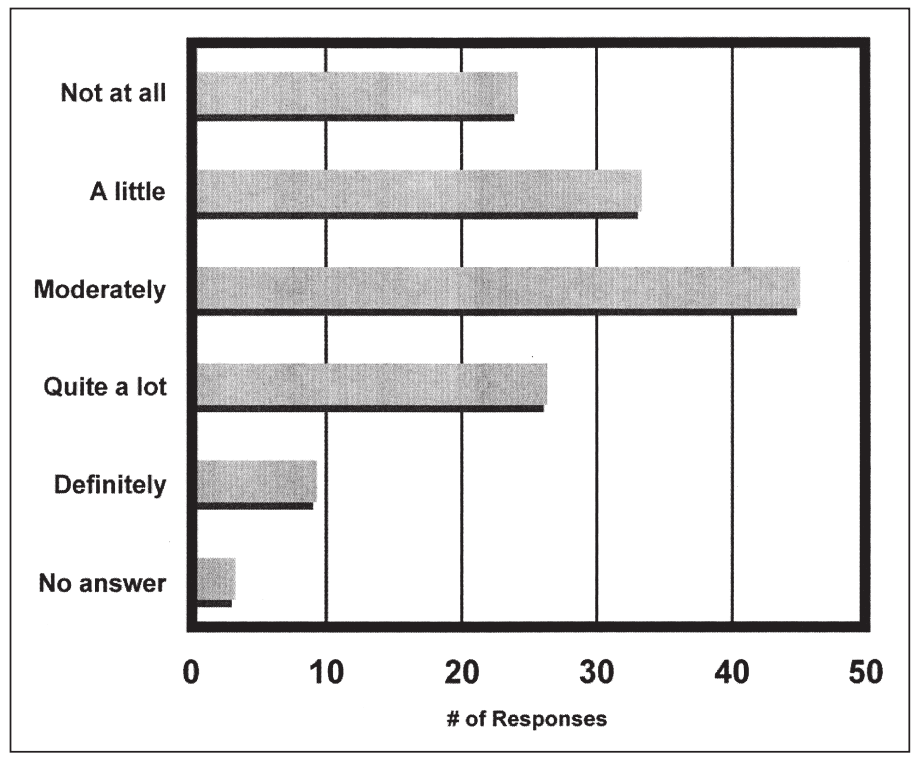

Figure 6. Would policies influence decisions?

Respondents were also asked if knowing that one publisher had a more generous copyright policy for authors than another publisher would influence their decision about the journal to which they submitted their article for publication. Figure 6 shows the degree of influence publishers' copyright policies had on authors' decision-making. A study conducted in 1999 found that "copyright was neither a major concern nor an important factor in an author's choice of publication." ${ }^{21}$

To determine where the library faculty members of the 10 institutions published their peer-reviewed articles, the article citations submitted by library administration and library faculty members were analyzed. Although it was determined that the library faculty members published in 55 different refereed journals during the five-year period, most articles were published in journals from Haworth (31), The American Library Association (21), Elsevier (17), and Emerald (16).

The SIUC researchers also asked if any of the respondents had attempted to improve their situation by negotiating for more author rights than were offered by the publisher. Only 10 respondents (7 percent) said they had negotiated for better intellectual property rights from their publisher(s), and only one person had tried and failed.

The Scholarly Publishing and Academic Resources Coalition (SPARC), the Joint Information Systems Committee (JISC) in the United Kingdom, and others actively encourage authors to archive electronic versions of their research articles in institutional repositories or to self-archive them on personal or departmental Web sites. In the context of this national and international activity, the SIUC researchers surveyed their library colleagues about their attitudes and experiences concerning self-archiving and institutional repositories. Only 16 survey respondents (12 percent) indicated that they had electronically archived their articles in an institutional repository (4 responses), on their personal Web site (7 responses), or on a departmental Web site (5 responses). Respondents could select all applicable responses, but none selected more than one venue 
for their archived articles. Respondents to the SIUC survey showed a lower rate of selfarchiving than the library and information science respondents to Swan and Brown's study indicated. ${ }^{22}$ In the CIBER study, 21 percent of respondents indicated that they had deposited scholarly materials in an institutional repository, ${ }^{23}$ as compared to 12 percent in the SIUC study who had chosen one of several forms of self-archiving. Therefore, further study would be useful to determine the reasons for a less self-archiving in the 10 institutions in the SIUC study.

When asked if they would deposit copies of their articles in an institutional or subject-based repository, if mandated by their institution, the overwhelming majority (89 percent) indicated that they would do so willingly. Seven percent (7 percent) replied that they would do so reluctantly. Two people (1 percent) indicated that they would not participate; one of the two commented that she/he would have answered, "Willingly, if permitted by the publisher," if that had been an option for this question. The other person commented that she/he publishes in academic press publications and has had no trouble with copyright. There was a high level of willingness to self-archive from all respondent groups: tenured and tenure track, assistant, associate, and professor. Statistical analysis indicated that any reluctance to self-archive could not be shown to depend upon either rank or tenure status. Swan and Brown's findings corresponded to these survey results and indicated that "the vast majority of authors (81 percent) would willingly comply with a mandate from their employer or research funding agency to deposit their articles in an institutional or subject-based repository." ${ }^{24}$

Respondents were given the opportunity to add comments at the end of the survey. A total of 48 (36 percent) chose to do so. As stated above, the faculty members of some institutions were asked to consider the inclusion of citations of their scholarly publications in the comments section of the survey, and four did so. Many of the comments included further explanation of answers to the other 10 questions.

Several respondents chose to explain other reasons for choosing a publisher or a journal as a potential outlet for their scholarly research. Some respondents said that a primary concern was the journal's reputation and peer-review status because of the importance in the promotion and tenure process. Others indicated that a journal's review period was a significant consideration, especially when the author was faced with tenure process deadlines. Some respondents cited philosophical or moral reasons for not choosing a particular publisher or journal for publishing their articles. Alternatives to the large publishing firms included journals owned by non-profit groups or more library-friendly publishers (such as Library Quarterly), a major association journal (such as College and Research Libraries), some of the new open access journals, and academic presses. Many respondents commented that they were very satisfied with the rights afforded by publishers of their articles and usually found them to be very generous. Some respondents indicated that a major reason for selecting a particular journal was the author's goal of reaching the audience serviced by that journal.

There were comments about other aspects of the survey and the scholarly publishing environment. Several respondents commented that when they successfully complete the tenure process, they will probably be more selective in their choice of journals and publishers. Their primary consideration while completing the tenure process was the timely publication of articles. Others indicated that their institution has different tracks 
for achieving tenure (such as "professional participation") for which a record of publication is not always required. Another person stated, "I would like to see my institution emphasize research and publication to a greater degree; it will, however, require us to free up some of our time to devote to the purpose." One respondent was concerned about the fact that some peer-reviewed journals are now requiring "hefty fees" from authors if articles are accepted for publication, although no journal titles were named. Another who writes primarily in the area of technology, noted that journals with a reputation for taking a long time to get articles into print were avoided to prevent the publication of outdated information.

\section{Relationship of Promotion and Tenure Policies and Publication}

The promotion and tenure policies of the 10 institutions were also reviewed. Although one policy stated that the "appointment as a librarian does not imply a specific major responsibility to engage in research and publication," ${ }^{25}$ most policies included phrases like "research and creative activity" or "contributions to the profession" as requirements for successfully completing the promotion and tenure process. As examples, the policies often mentioned articles, book chapters, and monographs as appropriate formats for research activities, but, as noted in the Florida study, ${ }^{26}$ rigorous definitions were generally not included. Some policies indicated that refereed and peer-reviewed journals "carry more weight" in the promotion and tenure process. At SIUC and at some other institutions, the number of articles or publications required for promotion and tenure is not specified in writing. At some institutions such as SIUC, however, it is commonly understood that there is an "expected" number. Only one peer institution of SIUC specified the number of publications needed for the process: "a scholarly monograph, or usually at least four articles in refereed journals, or the equivalent." ${ }^{27}$ Seventeen survey respondents from that institution reported having 41 refereed articles published during the past five years. The only institution that reported more published articles did not specify a number of articles necessary for promotion and tenure. Its 21 respondents reported 53 articles published during this period. The third most prolific faculty group reported 35 articles from the 11 respondents. Coincidentally, only two respondents from each of these three institutions reported having zero (0) articles published. The mean number of articles published per author for the five-year period at the top three institutions was $2.8,2.7$, and 3.8, respectively. This did not include faculty members who did not publish. The highest number reported by individual authors at these three institutions was 7 articles over the 5-year period. So, it is not possible to correlate the average number of publications per faculty member with quantifiable promotion and tenure requirements.

The survey responses showed instances of library faculty members who were prolific publishers and others who had no published articles. Three individual faculty members from the institutions surveyed reported 10 or more articles published during this period. Their totals were 14,12, and 10. They accounted for the bulk of the articles coming from their library faculties: 64 percent, 55 percent, and 37 percent, respectively. Other library faculty members who published articles at these institutions averaged 1.3 articles, 2 articles, and 2.4 articles, respectively. At two of these institutions where an 
individual faculty member published 10 or more articles and at two others, at least half of the respondents reported that they had not published any peer-reviewed articles in refereed journals in the last five years. Those who had not published recently were both tenured and untenured with slightly higher concentrations for those who received tenure before the year 2000 and those who had not yet received tenure. Of all the respondents (64) who received tenure more than five years ago, 39 percent (25) reported that they had not published in the last 5 years. Of those respondents (44) who were tenure track, 36 percent (16) had not yet published, even though several indicated that articles had been submitted but had not appeared in print.

It might be assumed that individuals who completed the promotion and tenure process recently would have been among the most active authors. Generally, the length of the tenure process is from three to six years. The eight respondents who were granted tenure in 2005 published a total of 33 articles during the last five years. The library faculty members who were tenured in 2005 averaged four articles apiece during this period. Of the 10 library faculty members who were tenured in 2004, six published 20 articles, for an average of 3.33 articles apiece. Four of their number reported zero articles published. Faculty members who received tenure before the year 2000 were also active authors. A total of 120 articles were published during the last five years by 39 librarians in this group, for an average of over three per individual. Those respondents who are not yet tenured reported that 28 (64 percent) of them published 69 articles, for an average of nearly 2.5 per person.

An analysis of this data showed that there was no appreciable difference between the overall level of publishing of tenured faculty and that of tenure track faculty. This analysis may be confounded because many of the tenure track faculty members may

\section{An analysis of this data showed that there was no appreciable difference between the overall level of publishing of tenured faculty and that of tenure track faculty.} be new to the process and would not have been publishing throughout the entire period. The researchers then examined the publishing record of faculty members who had most recently received tenure and compared it to those who had been tenured for five years or more and found a significant difference. It was reasoned that faculty

who had received tenure in 2004 and 2005 had been in the tenure process for most of the five-year period being examined. Those who received tenure in 2000 or before had not been subject to the tenure process during the period in question. Analysis showed that the mean number of articles for the more veteran group was 1.94, and for the newly tenured group it was 3.31. The t-test comparing publishing rates between these two groups showed that the value of $t$ was -2.148 , with 77 degrees of freedom, and the $p$ value equaled .035 , which is significant at the .05 level.

Faculty rank was also studied as a factor affecting the rate of scholarly publishing activity. The 27 respondents who had achieved the rank of professor published on average 1.85 articles over the five-year period, with a standard deviation of 2.38 . The 60 associate professors published at a mean rate of 2.94 articles with a standard deviation of 2.94 in the same time period. The 43 assistant professors had a mean publishing rate 
of 1.51 with a standard deviation of 1.70 . A one-way ANOVA $(F=2.09, \mathrm{p}=.057)$ did not provide enough evidence to conclude that publishing rates are different for the different faculty ranks. The results of the Florida study also showed that tenure track and promotion-earning respondents ranked books and articles as most important among research, publication, and service requirements. ${ }^{28}$

\section{Conclusions}

The results of the survey of library faculty members from 10 academic research libraries provided information and insights about the respondents' publishing decisions and self-archiving practices. Almost two-thirds of the survey respondents published at least one article in the last five years, with three articles as the mean and median number published by respondents during that period. Some authors published 10 or more during the five-year period.

The results of the questions related to the copyright and intellectual property rights of publishers, including self-archiving, compared with national and international data for faculty members in all disciplines showed that the library faculty members are not practicing what they generally advocate. They are not considering the copyright and intellectual property policies of publishers more often than the total faculty members in all disciplines. They are self-archiving on average about one-half as much as

of the few respondents who attempted to negotiate with their publishers for more intellectual property rights, most were successful. the total faculty members in a major international study. However, almost one-half indicated that their primary concern was the publication of their articles and that a publisher's copyright and intellectual property policies were not considered in selecting a journal for article submission. Of the few respondents who attempted to negotiate with their publishers for more intellectual property rights, most were successful. Most library faculty members would willingly deposit copies of their articles in an institutional or subject-based repository if their university mandated such action, but few respondents had self-archived any of their published articles in an institutional repository or on a personal or departmental Web site. In recent years, most publishers have changed their copyright transfer policies, so authors now are retaining more rights including the right to self-archive articles.

The written promotion and tenure policies related to publishing ranged from no requirement for researching and publishing articles to one with a stated minimum number of articles in peer-reviewed journals. For all of the institutions surveyed, there was no significant difference between the publishing activity of tenured faculty and tenure track faculty. The tenure process at some institutions seems to have been the primary motivating factor for some faculty members to publish scholarly articles, but many library faculty members continued to publish after receiving tenure and promotion. Even at institutions with no written emphasis on scholarly publishing, some library faculty members published regularly. Respondents at all faculty ranks were active authors, but the most prolific were those in the associate professor rank. 
The researchers recommend another study of the reasons why library faculty members do not seem to be more concerned with the copyright of their own materials and the extent of self-archiving of articles by library faculty members. The study should investigate the reasons for choosing or not choosing to self-archive and should measure any changes in attitude and perspective since this 2005 study. Such a study could include consideration of the possible leadership role of library faculty members in the self-archiving of research on their campus.

\section{Acknowledgement}

The authors wish to thank Mickey Soltys, instructional support services programmer, for his valuable assistance with the statistical analysis for this project.

Howard Carter is manager of instructional support services, Southern Illinois University Carbondale, IL; he may be contacted via e-mail at: hcarter@lib.siu.edu.

Carolyn A. Snyder is director of foundation relations, Southern Illinois University Carbondale, IL; she may be contacted via e-mail at csnyder@lib.siu.edu.

Andrea Imre is electronic resources librarian, Southern Illinois University Carbondale, IL; she may be contacted via e-mail at: aimre@lib.siu.edu.

\section{Notes}

1. Deborah B. Henry and Tina M. Neville, "Research, Publication, and Service Patterns of Florida Academic Librarians," The Journal of Academic Librarianship 30 (November 2004): 435.

2. Kathleen E. Joswick, "Article Publication Patterns of Academic Librarians: An Illinois Case Study," College \& Research Libraries 60 (July 1999): 340-9.

3. Richard L. Hart, "Scholarly Publication by University Librarians: A Study at Penn State," College \& Research Libraries 60 (September 1999): 454-62.

4. Stephen E. Wiberley, Jr., Julie M. Hurd, and Ann C. Weller, "Publication Patterns of U.S. Academic Librarians from 1998 to 2002," College \& Research Libraries 67 (May 2006): 205-15.

5. Ian Rowlands, Dave Nicholas, and Paul Huntingdon, "Scholarly Communication in the Digital Environment: What Do Authors Want? Findings of an International Survey of Author Opinion" (London: City University, 2004), http:/ / www.publishers.org.uk/paweb/ paweb.nsf / 0/ b93e724b16fbc7f880256ea9003b77ae/\$FILE/ciber-pa-report.pdf (accessed September 28, 2006).

6. Alma Swan and Sheridan Brown, "Open Access Self-Archiving: An Author Study," (Truro, UK: Key Perspectives Limited, 2005), http:/ / www.keyperspectives.co.uk/ openaccessarchive/reports/Open percent20Access percent20II percent20(author percent20survey percent20on percent20self percent20archiving) percent202005.pdf (accessed September 28, 2006).

7. Elizabeth Gadd, Charles Oppenheim, and Steve Probets, "RoMEO Studies 1: The Impact of Copyright Ownership on Academic Author Self-Archiving," Journal of Documentation 59, 3 (May 2003): 259.

8. Steven Harnad, "Free at Last: The Future of Peer-Reviewed Journals," D-Lib Magazine 5, 12 (December 1999), http: / / www.dlib.org/dlib / december99/12harnad.html (accessed September 28, 2006); Open Society Institute, “Budapest Open Access Initiative," Open 
Society Institute, http: / / www.soros.org/openaccess / read.shtml (accessed September 28, 2006).

9. Mark S. Frankel, "Seizing the Moment: Scientists' Authorship Rights in the Digital Age: Report of a Study by the American Association for the Advancement of Science" (American Association for the Advancement of Science, July 2002), http:/ / www.aaas. org/spp/sfrl/ projects / epub / finalreport.pdf (accessed September 28, 2006).

10. Peter Suber, "Removing the Barriers to Research: An Introduction to Open Access for Librarians," College \& Research Libraries News 64 (February 2003): 93.

11. Joint Information Systems Committee, Project RoMEO, http:/ /www.lboro.ac.uk/ departments/ls/disresearch/romeo/ (accessed September 28, 2006).

12. Gadd, Oppenheim, and Probets, 268.

13. SHERPA, "Publisher Copyright Policies \& Self-Archiving," University of Nottingham, http:/ / www.sherpa.ac.uk/ romeo.php (accessed September 28, 2006).

14. Lee C. Van Orsdel and Kathleen Born, "Choosing Sides," Library Journal 130, 7 (April 2005): 43-8.

15. Elizabeth Gadd, Charles Oppenheim, and Steve Probets, "RoMEO Studies 2: How Academics Want to Protect Their Open Access Research Papers," Journal of Information Science 29, 5 (September 2003): 340.

16. Swan and Brown, 30.

17. Anita Coleman and Joseph Roback, "Open Access Federation for Library and Information Science," D-Lib Magazine 11, 12 (December 2005), http: / / www.dlib.org/dlib/ december05/ coleman/12coleman.html (accessed September 28, 2006).

18. Rowlands, Nicholas, and Huntingdon, 11.

19. Southern Illinois University Carbondale, “Southern @150: Building Excellence Through Commitment," Southern Illinois University Carbondale, http:/ / news.siu.edu/s150/ (accessed September 28, 2006).

20. Rowlands, Nicholas, and Huntingdon, 14 .

21. Alma Swan and Sheridan Brown, What Authors Want: The ALPSP Research Study on the Motivations and Concerns of Contributors to Learned Journals (Truro, UK: Key Perspectives, 1999).

22. Swan and Brown, "Open Access Self-Archiving," 27.

23. Rowlands, Nicholas, and Huntingdon, 20.

24. Swan and Brown, "Open Access Self-Archiving," Executive Summary.

25. University of Kentucky Libraries, "Appointment, Promotion, and Tenure in the Librarian Series," http: / / www.uky.edu/Libraries / ptarls.pdf (accessed September 28, 2005).

26. Henry and Neville, 438.

27. Washington State University Libraries, "Library Faculty Handbook: Criteria for Merit Increases, Promotions, and Granting of Tenure," Washington State University, http:/ / www.wsulibs.wsu.edu / faculty / faculty-handbook/ Promotion-Granting-Tenure.html (accessed September 28, 2005).

28. Henry and Neville, 439. 